European

Journal of Marketing

28,5

36

Received July 1992

Revised A pril 1994
European Journal of Marketing, Vol. 28 No. 5, 1994, pp. 36-53. (c) M CB University Press, 0309-0566

\section{Religious Contrasts in Consumer Decision Behaviour Patterns: Their Dimensions and Marketing Implications}

\author{
Nejdet Delener \\ St John's U niversity, New York, USA
}

\section{Introduction}

Religion, being an aspect of culture, has considerable influence on people's values, habits and attitudes, and it greatly influences lifestyle, which in turn affects consumer decision behaviour[e.g. 1-3]. As Peterson and Roy[4] comment, one function of religion is to provide a source of meaning and purpose for people. Religion can provide a framework which makes life understandable and interpretable. A Ithough religion has been a significant force in the lives of many individuals, its role in consumer choice can be characterized as unclear or "fuzzy". First, religion serves to define the ways to do things (i.e. established practice) and to provide a series of tools and techniques for social behaviour[5-8]. Second, religion either fosters or frowns on particular choice behaviour $[9,10]$. Thus, despite the potential importance of the religion or religiosity constructs, any empirical investigation of these constructs in consumer behaviour has been rare.

More generally, the religions practised in a society influence husband/wife decision-making roles, as well as societal institutions and customs. It has been suggested that religious orientation is a strong influence on the development of family commitment in giving the family a sense of purpose and values oriented to the need and welfare of others[e.g. 11,12]. Commitment, in the causal sequence, is assumed to influence family time and effort. Religious devoutness indirectly influences commitment by directly affecting relationship qualities (i.e. love/caring), locus of control and gender roles which in turn directly influence commitment[11].

Little empirical information is available on the relationship between family values and religion. M ost of the literature on families and religion falls into one of four categories:

(1) Studies of the effects religious beliefs and involvements have on familyrelated behaviours - divorce, sexual behaviour, and the like[e.g. 13,14].

(2) Studies of the effects religious beliefs and involvements have on attitudes about gender roles, sexuality, family life[e.g. 15-17].

(3) Studies of the transmission of religious allegiance through families[e.g. $18,19]$. 
(4) Studies of religious intermarriage[e.g. 6,20].

Consumer

All these studies have examined the relationship between religious variables and attitudes/behaviours from sociological and psychological points of view. Less attention has been paid to the relationship between religiosity and consumer purchase decisions. Furthermore, no multidimensional study which investigated the religious dimension and orientation that correlate with purchasing roles had ever been reported. This research is, therefore, designed to explore the relationships between religiosity and consumer-related marital roles in the process of automobile purchase decision making.

The remainder of the article is organized into four sections. T he next section, background, presents major propositions and the research findings relating religiosity and family decision roles. This is followed by a paradigm showing relationships among religion, religiosity and household consumer decisionmaking patterns. The third section, methodology, describes the data collection and measurement procedures. The article concludes with a discussion of the results obtained from testing the hypotheses and their implications.

\section{Conceptual Background}

The primary goal of this study is to explore the hypothesized differences in consumer-related marital roles of Catholic, Jewish, pro-religious and nonreligious households; therefore this review will focus on relevant available literature. W hile Catholic families are frequently labelled patriarchal in structure, there have been few empirical studies in which the family has been the primary focus. Several sociologists have reported that the depiction of Catholic families often focuses on a rigid and authoritarian structure by a macho male[21-23]. A s Borowski[24] characterizes Catholicism, a sub-culture is a way of life. It is derived from and maintained by abiding family ties. It influences self-identity and fundamental values. However, in contrast withCatholic families, the Jewish family structure seems to be more democratic and can best be termed "family-centred". Thus in Jewish households decisions seem to be made jointly[e.g. 25-27].

M ost studies of religion relevant to family-related behaviours have been conducted within the fields of sociology, anthropology and psychology. For example, Bahr[28] studied the denominational differences in marital role definitions and role enactment among Catholics, Protestants and Mormons. In Bahr's study, three areas of role behaviour were examined:

(1) role performance (the actual divisions of role tasks in the respondent's own family);

(2) family power (the division of decision making);

(3) family conflict (degree of inter-spousal disagreement over selected roles).

Results suggest that, in child socialization roles, Catholics were more likely than the other religious groups to state that both spouses were equally responsible for teaching and disciplining children. A degree of male dominance in the 


\section{European \\ Journal of Marketing 28,5}

settling of family disputes was apparent among all religious groups. A bout half the Catholic respondents stated that the husband exerted more influence than the wife in resolving recent family conflicts; the findings did not show any evidence of unusual matriarchal dominance in Catholic families. However, comparing research from Mexico, Puerto Rico, England and the USA, Rainwater[29] found that Catholic males from all areas suffer from job insecurity and compensate for their feelings of inferiority by exaggerating their masculinity and subordinating women. This might suggest that machismo may be due to feelings of inferiority, which men try to hide by acting superiorly[30]. This is accomplished by avoiding feminine and emphasizing strong masculine traits.

Brinkerhoff and MacKie[15] also studied gender behaviours such as familial power and division of household labour of Catholics, M ormons and Protestants. Findings suggest that, in terms of familial power, M ormons are among the most egalitarian. How ever, Roman Catholics appeared far more egalitarian than other studies reported[e.g. 22]. Their findings showing Roman Catholics to be egalitarian are consistent with M eir[31] and Campbell[32]. The most traditional group appeared to be Protestants.

The only study reported in marketing literature includes Delener and Schiffman's study[33] which examined the role structure of Catholic and J ewish households. Their findings suggest that in Catholic households husbands were the major influence in making specific purchase decisions. In contrast, in J ewish households husbands and wives shared equally in making most decisions. A lthough the relationship between religion/religiosity and decision making has not been extensively investigated, it is clear that marketing researchers are increasingly paying attention to the religiosity construct. For example, Engel[34] studied the psychographic profiles of two different denominations in Brazil. Other researchers examined the influence of religious background on consumption innovativeness[35,36], purchase risk aversion[1] and selected retail store patronage behaviour[37,38].

The limited available research suggests that religiosity, as a segmentation variable, has been recognized as one of the most important cultural forces and a key influence in buyer behaviour. Therefore studying the influence of the religious construct on consumer decision making is important owing to its stability over time and the observable nature of many of its elements.

\section{Religious Influence/Role Structure Paradigm}

A simple paradigm (Figure 1) shows the religious variables as they were hypothesized in the study to influence consumer-related marital roles in purchase decision making. Religiousness, as an important value in the individual consumer's cognitive structure, can influence an individual's behaviour. Furthermore, religiousness may play a significant general role in the problem-solving and decision-making processes[e.g. 39-41]. For example, Pargament[42] has noted that religion may serve important functions in hel ping people understand and cope with life events by offering guidance, support and 

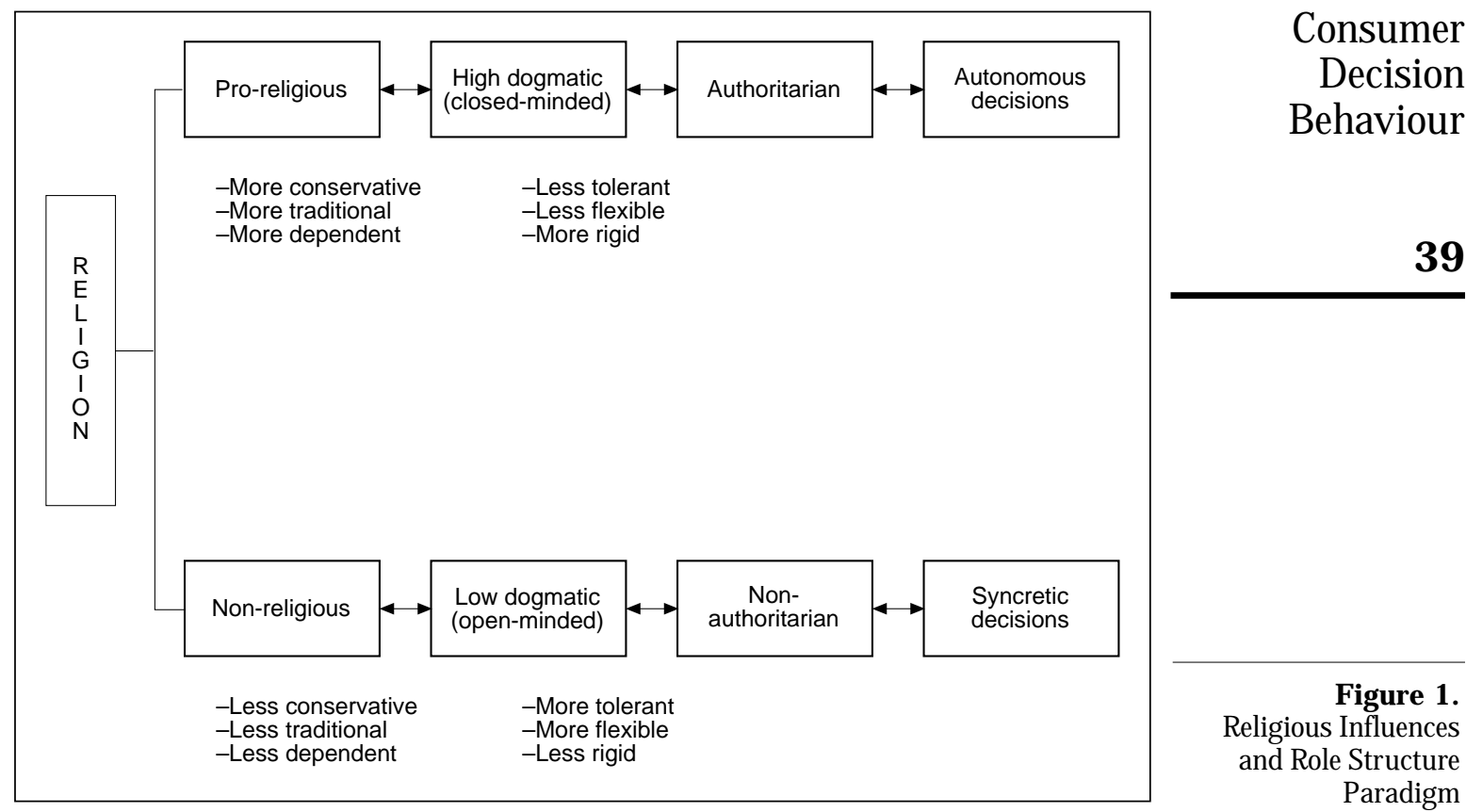

hope. Spilka et al.[43] see religion as providing a frame of reference for individuals to help them understand, predict and control events, and to maintain self-esteem. Wilson[44] concludes "religion is probably the single most important shaper of sex roles". People's ideas about gender, both role and attitude, derive from socialization which occurs within the family setting, and has traditionally been guided by religious norms[e.g. 45,46]. Still further, M cM urry [22, p. 83] considers religion and family as reactive institutions which exert conservative influences and concludes, "the subjects who are exposed to more of this influence through greater religious involvement should be more traditional".

More specifically, religion represents a potentially significant element in many, if not all, the problem-solving and decision-making phases. For example, as recent research in religious attribution theory suggests, religion may affect how one understands the meaning of many problems[47,48]. Similarly, religious beliefs and practices may guide the individual in the process of selecting solutions to problems. Religion may also provide the individual with emotional support throughout the problem-solving and decision-making processes, particularly during stressful periods[42]. Research hypotheses are discussed next.

Research Hypotheses: Religion and Decision Behaviour Patterns From various kinds of data, there is considerable evidence that a generally consistent positive correlation exists between religious conservatism and 


\section{European \\ Journal of Marketing 28,5}

authoritarianism[e.g. 49-51]. In examining this relationship, some theorists contend that because of the organized structure of religion and its place in childbearing, religious systems foster authoritarian persons[52]. Others, however, argue that, given certain personality dispositions, certain religious content is usually more congenial[53]. In any event, particular religious beliefs seem to fit more easily into authoritarian patterns, and the cognitive structure of authoritarianism seems to be more congenial with particular types of religion[49,54].

A dorno et al.[55] assumed authoritarianism to be a syndrome that would make a person very susceptible to anti-democratic movements. A uthoritarianism consists of nine traits: conventionalism, power orientation, submission, aggression, anti-intraception (i.e. rejection of self-reflection), superstition, cynicism, projectivity and excessive fixation on sexuality[e.g. 56]. These traits point to the psychoanalytic perspective of A dorno and his colleagues, who tried to explain the development of the authoritarian personality by describing its typical family background. A $n$ authoritarian person would have been raised in a family with a dominant, status-oriented father and a very restrictive mother. In this family, every tendency towards disobedience would have been strongly suppressed; therefore a premature and complete identification, also with submission to the powerful parents, would follow.

Some researchers have ventured the interpretation, as suggested by A dorno et al.[55], that the personality characteristic of dogmatism is the common basis of the correlation between conservative attitudes and religion. Studies have found that religiousness appears to occur most frequently in rather well-defined religious groups, those which are conservative in dogma[e.g. 57,58]. Greel ey[59] reasoned that, if differences in conservative attitudes between Catholics and Jews were attributable to religious influences, conservatism (traditionalism and dogmatism) should be greater among those who could be regarded as more religious with their tradition.

The existing literature collectively suggests considerable evidence of a high degree of authoritarianism and conservatism among Catholics. Vosburgh and Juliani[60], for example, reported that Catholics had more conservative views than those in other religious groupings. Findings of another study suggested that a group of Catholic students scored relatively high on the Authoritarian Scale (F-Scale) as well as on the dogmatism, opinionation and ethnocentrism scales[61]. Similarly, studies by Warshay et al.[62] reported higher authoritarian scores for Catholic samples. Jones[39], in a study of naval aviation cadets, also found that those scoring high on the A uthoritarian Scale were more likely to be Roman Catholic than Jewish. Hence the following research hypotheses were developed and tested in the present study:

$\mathrm{H}$ la. The roles of husbands and wives in Catholic, Jewish, pro-religious and non-religious households vary over the course of consumer decisionmaking processes. 
H1b. Catholic households are prone to husband-dominated decision making.

H1c. J ewish households are prone to syncratic consumer decision making.

\section{Religiosity and Decision Behaviour Patterns}

From a biblical perspective, pressure for obedience to an authority must always be assessed in the light of the effects such obedience would have on the persons involved. Religious believers have often placed primary emphasis on obedience and have relegated man's responsibility for the protection of his partner to a position clearly secondary[63-65]. For instance, within the religious structure children have been taught to obey authority unquestioningly; they have not been taught to assess critically the legitimacy of the authority's demands. Thus individuals who are deeply embedded in this structure would be expected to obey authority to the exclusion of other values. The ability to make firm decisions has perhaps become part of their lifestyle. Thus those who are strongly committed to religion are both attitudinally and behaviourally capable of making decisions consistent with moral conscience[41,63,66,67]. A the same time, non-religious extremists can become committed to an authoritarian structure of their own. They may find themselves caught in the web of excessive submission to the authority of their own value structure.

Religious moderates have their values more in balance; while they recognize the importance of obedience to authority, they evaluate that authority in the light of their concern for other men. Religious moderates may be unaccustomed to firm decision making. There are also the agnostics - those who "do not know for sure". In the presence of such indecision, they are willing to have the momentary decisions of life made for them. In the Bock and Warren[63] study, these less decisive individuals were compelled to surrender moral conscience to a seemingly knowledgeable and decisive person. Only those accustomed to independent decision making could resist. The biblical position is that the man who is undecided about basic religious issues is unable to be decisive when confronted by an ethical dilemma. His tendency is to forfeit his choice to any impinging power. On the other hand, having taken a definite religious stance, one will act in accordance with his conscience.

Research indicates that pro-religious individuals are likely to be more dogmatic[61,68,69], more conservative[62,70], and more authoritarian[52-54] than are the non-religious subjects. In particular, Frenkel-Brunswick[52] cites the authoritarian's tendency to rigid, exaggerated sex-role stereotypes that stress clearly defined roles of dominance and submission in husband/wife and general male/female relationships. Dichotomous sex-role conceptions within the authoritarian family emphasize exaggerated masculine and feminine characteristics[e.g. 71-73]. Johnson et al.[74] found that authoritarian subjects from entrepreneurial backgrounds were more restrictive than nonauthoritarians in the number of behaviours they considered appropriate for children of both sexes. As authoritarianism is positively correlated with 


\section{European \\ Journal of Marketing 28,5}

religiosity, it is therefore predicted that individuals with pro-religious orientations are more likely to make autonomous decisions. The profile of the autonomous decision mode suggests a family with traditional values and attitudes towards marital roles. The power to make a decision is influenced by prescribed authority [e.g. 33,75,76]. This leads to the following research hypotheses within the context of the consumer purchase decision process:

H2a. For Catholic and Jewish households, the higher the religious orientation, the greater the occurrence of autonomous consumer decisions.

$\mathrm{H} 2 \mathrm{~b}$. For Catholic and J ew ish households, the lower the religious orientation, the greater the occurrence of syncratic consumer decisions.

H3a. For Catholic and Jewish households, the higher the perceived religious affiliation, the greater the occurrence of autonomous consumer decisions.

$\mathrm{H} 3 \mathrm{~b}$. For Catholic and Jewish households, the lower the perceived religious affiliation, the greater the occurrence of syncratic consumer decisions.

\section{Methodology: Data Collection Procedures and Sample}

Data were collected from up-scale Catholic and Jewish households residing in the North-E ast region of the USA who had purchased a new automobile within the past year. The typical respondent was between 35 and 44 years of age, had at least some college education, and came from a nuclear family. A comparatively up-scale sample was selected because, first, the overall objective of this research is not to measure absolute occurrences in the society, but rather to explore relationships existing between variables and, second, up-scale samples may even be desirable in this type of research. A s was pointed out by Hirschman[36], a study using religion as an independent variable is perhaps better served by surveying the more up-scale consumer, since doing so allows better control for socio-economic differences known to exist among religious groups. The systematic sample was used as a selection procedure in this research and the sampling frame containing 1,500 households was obtained from a well- established list supply company.

A letter describing the study and ensuring respondents' anonymity in any published results was mailed to every second household on the list. A total of 750 questionnaires were then hand-delivered (and later collected) by the 24 trained screening interviewers. A fter discarding unusable questionnaires owing to severe omissions and end-piling, 207 (131 Catholics and 76 J ews) of the collected questionnaires were included in the database, yielding a response rate of 28 per cent. The somewhat low response rate may perhaps be attributed to the length of the questionnaire. Furthermore, members of any other religious groups (primarily Protestants) were excluded because the research was to focus on perceived differences in the consumer-related marital roles of the largest minority religious groups in the USA. 


\section{Measurement of Study Variables}

To measure influence and marital role orientation, principal decision-makers were asked to recall the manner in which various consumer decisions had been made in these households. For each automobile sub-decisions and decisions in general, each spouse indicated the degree of his/her perceived influence based on a five-point scale. The decision components represented eight common and relevant dimensions of purchase, e.g. problem/need recognition, search for information, what make, what model, what colour, when, where to buy and how much to spend. A $n$ automobile was selected as a household decision-making object because it met the selection criteria of other products in previous household decision studies[e.g. 33,76], that is it requires substantial financial outlay, has an extended period of ownership and is shared by several household members. In measuring the effect of religious factors on family purchasing roles, three independent variables were used. These variables and their operational definitions are presented in Tablel.

\section{Reliability Testing}

In this study Cronbach's[77] popular unidimensional coefficient alpha was used to test reliability. It is an estimate of the correlation between random samples of items from a universe of items and is an appropriate index of equivalence. This measurement, in effect, produces the mean of all possible split-half coefficients resulting from different splittings of the measurement instrument[78]. Internal consistency reliabilities (coefficient alphas) of the religiousness and purchase decision scales were 0.84 and 0.89 respectively. Based on Nunnally's criteria it is important to note that the scales' reliabilities are very large in magnitude. This indicates a high degree of internal consistency. A ccording to Nunnally[79]:

What a satisfactory level of reliability is depends on how a measure is being used. In the early stages of research on predictor tests or hypothesized measures of a construct, one saves time and energy by working with instruments that have only modest reliability, for which purpose reliabilities of 0.60 or 0.50 will suffice (p. 226).

Measuring reliability this way is appropriate for buyer behaviour research and has been used by several researchers [e.g. 35,80].

\section{Analysis and Findings}

Multivariate analysis of covariance (M A NCOVA) was used to test research hypotheses. The following discussion will explore these statistical analyses.

A s indicated in Table II, religious orientation effect and religion by religious orientation interaction were significant in determining marital roles in automobile purchase decisions. For the religious orientation, M A NCOVA findings were significant for questions concerning search for information, when to purchase, where to purchase and what model to purchase. As is indicated in Table V, the pro-religious households search for information jointly (2.8737) more than non-religious households (2.1696). Non-religious households decided jointly when to purchase automobiles (2.6429) more than pro-religious 


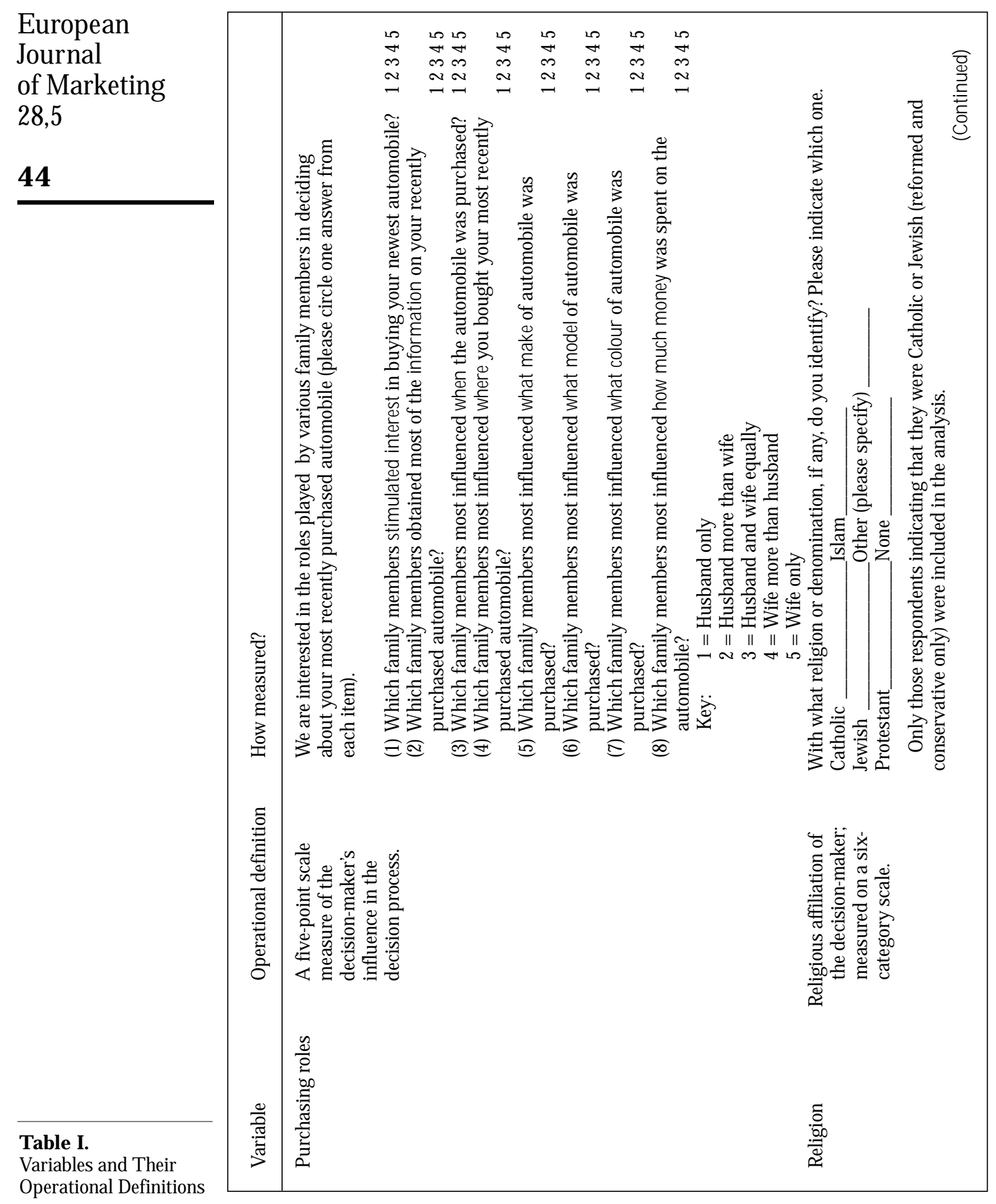




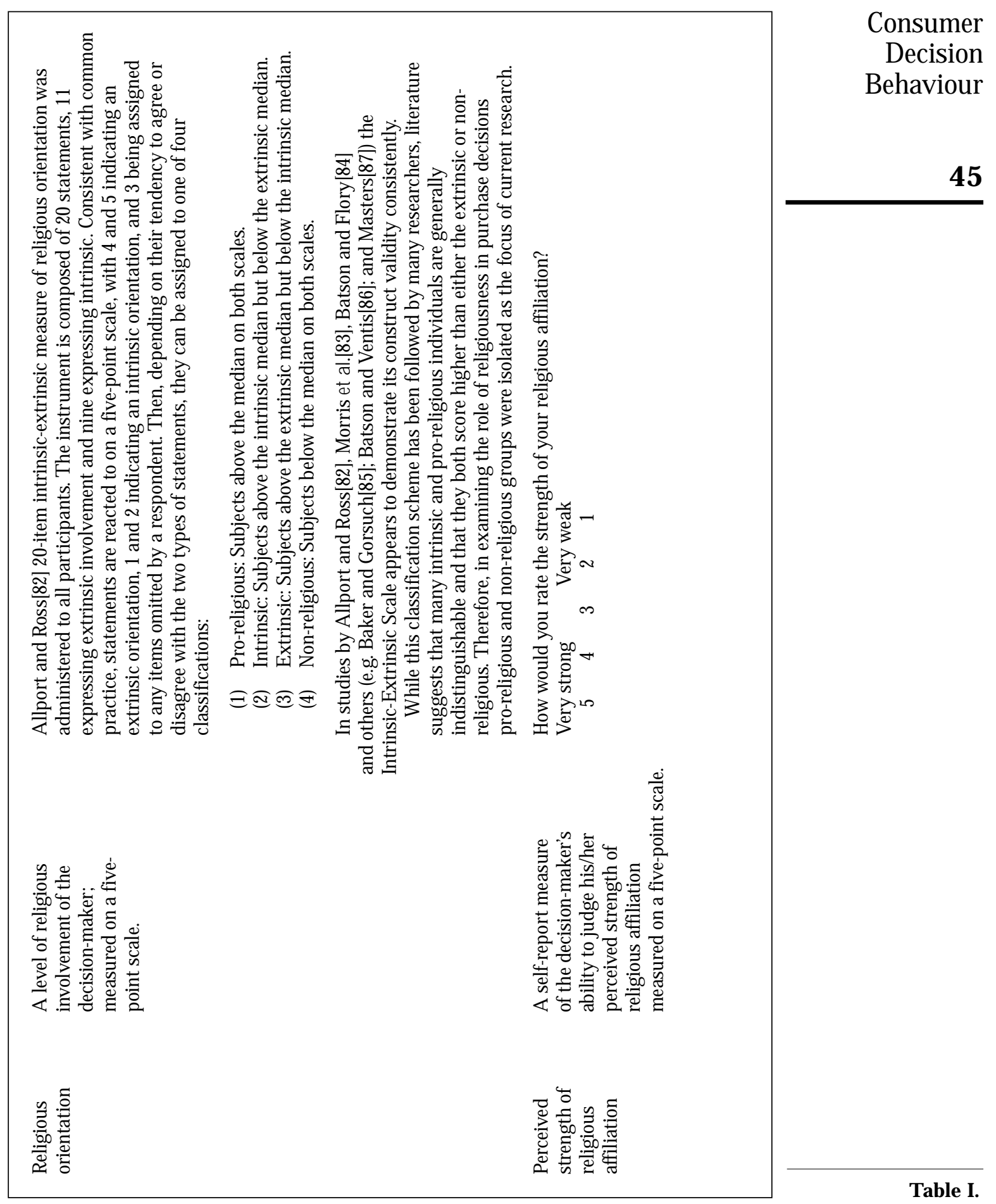




\section{European Journal of Marketing 28,5}

households (2.3263). Furthermore, the non-religious households decided jointly where to purchase the automobile (2.5000) compared with pro-religious households where husbands were the dominant influence in deciding where to purchase an automobile (2.1684). A similar pattern was also found with regard to the questions concerning what model automobile to purchase. The nonreligious households were more likely to decide jointly what model automobile to purchase (2.7321).

Furthermore, the findings suggest that religion by religious orientation interact for the questions concerning where and what colour automobile to purchase. Within the context of the non-religious orientation, Jewish households were more likely to decide jointly where to purchase an automobile (3.0370) compared with Catholic households which tended to be husbanddominated (2.3294). In contrast, for the pro-religious orientation, Catholic households were more likely to decide jointly where to purchase an automobile (2.3913) compared with Jewish households which were more likely to be husband- dominated (1.9592). The findings also suggest an interaction betw een religion and religious orientation for the decision of what colour automobile to purchase. For those with non-religious orientation, Jewish households were more likely to decide jointly what colour automobile to purchase (3.1481) than Catholic households where wives were the dominant influence in deciding the colour of the automobile (3.4353). Furthermore, for those with pro-religious

\begin{tabular}{|lcccc|}
\hline Effect & Hotelling & F & DF & Significance \\
\hline Religion & 0.074 & 1.812 & 8,195 & 0.077 \\
Religious orientation & 0.144 & 3.518 & 8,195 & 0.001 \\
Religion by religious orientation & 0.134 & 3.259 & 8,195 & 0.002 \\
Perceived strength of religious affiliation & 0.038 & 0.925 & 8,195 & 0.497 \\
\hline
\end{tabular}

\begin{tabular}{|lrc|}
\hline Marital roles & $F$ & Significance \\
\hline Obtained information & 5.923 & 0.016 \\
Influenced when to purchase & 5.737 & 0.018 \\
Influenced where to purchase & 16.903 & 0.000 \\
Influenced what model to purchase & 4.793 & 0.030 \\
\hline
\end{tabular}

\section{Table IV.}

Religion by Religious Orientation Interaction on Marital Roles in A utomobile Purchase Decisions 


\begin{tabular}{|c|c|c|c|c|c|}
\hline & Marital roles & Religion & Non-religious & $\begin{array}{c}\text { Religious } \\
\text { orientation } \\
\text { Pro-religious }\end{array}$ & $\begin{array}{l}\text { Total mean } \\
\text { for religion }\end{array}$ \\
\hline 1. & $\begin{array}{l}\text { Stimulated } \\
\text { interest in } \\
\text { automobile }\end{array}$ & $\begin{array}{l}\text { Catholic } \\
\text { Jewish }\end{array}$ & $\begin{array}{l}2.6589 \\
2.6667 \\
2.6607\end{array}$ & $\begin{array}{l}2.8043 \\
2.5510 \\
2.6737\end{array}$ & $\begin{array}{l}2.7099 \\
2.5921 \\
2.6667\end{array}$ \\
\hline 2. & $\begin{array}{l}\text { Obtained } \\
\text { information }\end{array}$ & $\begin{array}{l}\text { Catholic } \\
\text { Jewish }\end{array}$ & $\begin{array}{l}2.1177 \dagger \\
2.3333 \\
2.1696^{*}\end{array}$ & $\begin{array}{l}2.0435 \\
1.7143 \\
2.8737\end{array}$ & $\begin{array}{l}2.0916 \\
1.9342 \\
2.0338\end{array}$ \\
\hline 3. & $\begin{array}{l}\text { Influenced } \\
\text { when to } \\
\text { purchase }\end{array}$ & $\begin{array}{l}\text { Catholic } \\
\text { Jewish }\end{array}$ & $\begin{array}{l}2.5529 \\
2.9259 \\
2.6429 *\end{array}$ & $\begin{array}{l}2.4130 \\
2.2450 \\
2.3263\end{array}$ & $\begin{array}{l}2.5038 \\
2.4868 \\
2.4976\end{array}$ \\
\hline 4. & $\begin{array}{l}\text { Influenced } \\
\text { where to } \\
\text { purchase }\end{array}$ & $\begin{array}{l}\text { Catholic } \\
\text { Jewish }\end{array}$ & $\begin{array}{l}2.3294 \dagger \dagger \\
3.0370 \\
2.5000^{* *}\end{array}$ & $\begin{array}{l}2.3913 \\
1.9592 \\
2.1684\end{array}$ & $\begin{array}{l}2.3511 \\
2.3421 \\
2.3478\end{array}$ \\
\hline 5. & $\begin{array}{l}\text { Influenced } \\
\text { what make } \\
\text { to purchase }\end{array}$ & $\begin{array}{l}\text { Catholic } \\
\text { Jewish }\end{array}$ & $\begin{array}{l}2.6235 \\
2.6296 \\
2.6250\end{array}$ & $\begin{array}{l}2.5000 \\
2.3265 \\
2.4105\end{array}$ & $\begin{array}{l}2.5802 \\
2.4342 \\
2.5266\end{array}$ \\
\hline 6. & $\begin{array}{l}\text { Influenced } \\
\text { what model to } \\
\text { purchase }\end{array}$ & $\begin{array}{l}\text { Catholic } \\
\text { Jewish }\end{array}$ & $\begin{array}{l}2.6706 \dagger \\
2.9259 \\
2.7321^{*}\end{array}$ & $\begin{array}{l}2.4565 \\
2.3265 \\
2.3895\end{array}$ & $\begin{array}{l}2.5954 \\
2.5395 \\
2.5749\end{array}$ \\
\hline 7. & $\begin{array}{l}\text { Influenced } \\
\text { what colour to } \\
\text { purchase }\end{array}$ & $\begin{array}{l}\text { Catholic } \\
\text { Jewish }\end{array}$ & $\begin{array}{l}3.4353 \dagger \dagger \\
3.1481 \\
3.3661\end{array}$ & $\begin{array}{l}2.8696 \\
3.4898 \\
3.1895\end{array}$ & $\begin{array}{l}3.2366 \\
3.3684 \\
3.2850\end{array}$ \\
\hline 8. & $\begin{array}{l}\text { Influenced } \\
\text { how much } \\
\text { money spent }\end{array}$ & $\begin{array}{l}\text { Catholic } \\
\text { Jewish }\end{array}$ & $\begin{array}{l}2.4823 \\
2.6296 \\
2.5179\end{array}$ & $\begin{array}{l}2.1739 \\
2.3469 \\
2.2632\end{array}$ & $\begin{array}{l}2.3740 \\
2.4474 \\
2.4010\end{array}$ \\
\hline Key & $\begin{array}{r}\text { Significant } \\
* p<0.05 \\
* * p<0.01 \\
\text { Significant } \\
+p<0.05 \\
+\dagger p<0.01\end{array}$ & main effect & & & \\
\hline
\end{tabular}

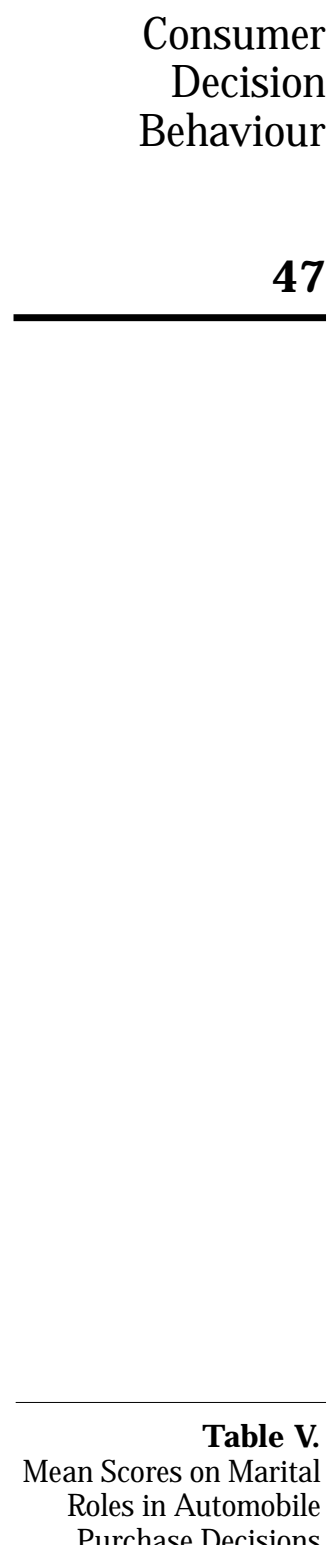

orientation, Catholic households were more likely to decide jointly what colour automobile to purchase (2.8696) compared with Jewish households where wives were the dominant influence in deciding the colour of the automobile (3.4898).

\section{Discussion and Implications}

Findings of this study, as expected, suggest that differential role behaviour varies according to religious influences, and, on balance, provide support for 


\section{European \\ Journal of Marketing 28,5}

Sheth's[3] theory of family buying decisions. Furthermore, findings of this research add to the understanding of fundamental consumer behaviour processes. Engel et al.[81] noted in their summary of the literature that differential role behaviour varies according to socio-cultural influences, type of product and decision stages. Clearly, the stage in the decision process has been shown to be an important element in role structure. Findings suggest that role structure varies over the course of the automobile purchase decision-making process owing to the respondents' religious affiliation and religious orientation. Hence, $\mathrm{Hl}$ a is supported. For example, in pro-religious Jewish households and pro-religious households in general, husbands exerted more influence in deciding where to purchase an automobile. This is consistent with M cM urry's[22] conclusion that stated the more religiously involved would portray more traditional gender attitudes.

Results did not show any significant religion and perceived strength of religious affiliation influences on role structure. Hence, $H 1 b, c$ and $H 3 a, b$ are not supported. However, the analysis demonstrates significant findings for the religious orientation and decision behaviour patterns. For example, in proreligious Catholic households, husbands and wives jointly decided where to purchase and what colour of automobile to purchase, whereas, in pro-religious Jewish households, husbands and wives decided when to purchase, and what colour of automobile to purchase respectively. T hese results, taken together, provide partial support for $\mathrm{H} 2 \mathrm{a}$. In contrast, in non-religious J ew ish households, husbands and wives decided jointly where to purchase and what colour of automobile to purchase. Therefore the evidence in Table V provides support for $\mathrm{H} 2 \mathrm{~b}$.

Results of this study suggest that marketers should seek a niche within a given market. Marketing should not be seen as a quick-fix solution for current problems, but rather entailing sensitivity in meeting the needs and wants of the consumers served. Specifically, in advertising, promotion, direct sales, etc., the importance of the decision-maker's religiousness must be considered. If his/her role in the decision-making process is ignored or treated as unimportant the sale of that product or service may be lost.

In general, marketing and consumer behaviour researchers have been concerned with the relative influence of husbands and wives in various decisions because of the implications role differentiation may have for product planning, advertising content and media, and choice of distribution channels. Specifically, enhanced knowledge of religious differences in consumption decision processes should have significant impact on the effectiveness of global marketing strategies and tactics. In particular, for promotion strategies, the appropriate communications target should be more clearly identifiable. A lsosuch knowledge should serve as a guide to development of more suitable message content and appeals. This knowledge may also have implications for distribution and product variables. In this way, marketing strategists can more effectively encounter the needs of diverse religious groups. 
W hile these findings are interesting and yield potentially valuable implications, one should recognize the inherent limitations associated with generalizing these findings beyond the sample utilized, its geographic scope, and the product category examined. Future investigations should therefore attempt to go beyond this basic conceptualization and methodology. They should investigate a number of product and service categories. In addition, there is great need for expansion of the religions investigated. Other issues that

need to be studied include purchase timing and variations in product and service evaluative criteria among household members. Furthermore, with global marketing increasing in importance it will be desirable to explore the implications of religiousness on marketing ethics, politics and the economic marketing systems. A dditional buyer behaviour studies to examine religion further as a background variable influencing hedonic consumption changes in consumer values would be a contribution.

\section{References}

1. Delener, N., "T he Effects of Religious Factors on Perceived Risk in Durable Goods Purchase Decisions", T he Journal of Consumer Marketing, Vol. 7, Summer 1990, pp. 27-38.

2. Hirschman, E.C., "Religious A ffiliation and Consumption Processes: A Preliminary Paradigm", in Sheth, J. (Ed.), Research in M arketing, Vol. 6, JA I Press, Chicago, IL, 1982, pp. 131-70.

3. Sheth, J.N., "A Theory of Family Buying Decisions", in Sheth, J.N. (Ed.), M odels of Buyer Behaviour: Conceptual, and Empirical, Harper \& Row, New York, NY, 1974, pp. 17-33.

4. Peterson, L.R. and Roy, A., "Religiosity, A nxiety, and M eaning and Purpose: Religion's Consequences for Psychological Wellbeing", Review of Religious Research, Vol. 27, 1985, pp. 49-62.

5. Bossard, J.H.S. and Boll, E.S., Ritual in Family Living, University of Pennsylvania Press, Philadel phia, PA, 1950.

6. Dudley, M.G. and Kosinski, F.A .Jr, "Religiosity and Marital Satisfaction: A Research Note", Review of Religious Research, Vol. 32, September 1990, pp. 78-86.

7. Engel, J.F. and Blackwell, R.D., Consumer Behaviour, 4th edition, Dryden Press, Chicago, IL, 1982.

8. Schwab, R. and Petersen, K.U., "Religiousness: Its Relation to Loneliness, Neuroticism and Subjective Wellbeing", Journal for the Scientific Study of Religion, Vol. 29, 1980, pp. 335-45.

9. Hawkins, D.J., Coney, K .A . and Best, R.J., Consumer Behaviour: Implications for M arketing Strategy, Business Publications, Dallas, TX, 1980.

10. Schiffman, L.G. and Kanuk, L.L., Consumer Behaviour, 4th edition, Prentice-Hall, Englewood Cliffs, New Jersey, NJ, 1991.

11. Larson, L.E. and Goltz, J.W., "Religious Participation and M arital Commitment", Review of Religious Research, Vol. 30, June 1989, pp. 387-99.

12. Scanzoni, J. and A rnett, C., "Enlarging the Understanding of Marital Commitment via Religious Devoutness, Gender-role Preferences, and Locus of Control", Journal of Family Issues, Vol. 8, 1987, pp. 135-56.

13. Glenn, N.P. and Shelton, B.A., "Pre-A dult Background Variables and Divorce: A Note of Caution about Over-reliance on Explained Variance", Journal of Marriage and the Family, Vol. 45, 1983, pp. 405-10.

14. Watson, P.J., Folbrecht, J., Morris, R. and Hood, R.W. Jr, "Values, 'Irrationality' and Religiosity", Journal of Psychology and Theology, Vol. 18, 1990, pp. 348-62. 


\section{European Journal of Marketing 28,5}

15. Brinkerhoff, M.B. and Mackie, M.M., "Religious Denominations Impact upon Gender A ttitudes: Some M ethodological Implications", Review of Religious Research, Vol. 25, June 1984, pp. 365-78.

16. Hartman, M. and Hartman, H., "Sex-Role A ttitudes of Mormons vs. Non-M ormons in Utah", Journal of M arriage and the Family, Vol. 45, 1983, pp. 897-902.

17. Wilcox, C., "Religion and Politics among White Evangelicals: The Impact of Religious Variables on Political A ttitudes", Review of Religious Research, Vol. 32, September 1990, pp. 27-42.

18. Hoge, D.R., Petrillo, G.H. and Smith, E.I., "Transmission of Religious and Social Values from Parents to Teenage Children", Journal of M arriage and the Family, Vol. 44, 1982, pp. 569-80.

19. Richards, P.S., "T he Relationshp between Conservative Religious I deology and Principled M oral Reasoning: A Review", Review of Religious Research, Vol. 32, June 1991, pp. 359-68.

20. Johnson, R.A., Religious A ssortative Marriage in the United States, A cademic Press, New York, NY, 1980.

21. Alvirez, D. and Bean, F.D., "The Mexican-A merican Family", in M indel, C.H. and Habenstein, R.W. (E ds), Ethnic Families in A merica, Elsevier, New York, NY, 1976, pp. 43243.

22. M cM urry, M., "Religion and Women's Sex Role T raditionalism", Sociological Forces, Vol. 11, 1978, pp. 81-95.

23. Ramirez, M., Psychology of A mericans: Mestizo Perspectives on Personality and M ental Health, Pergamon Press, New York, NY, 1983.

24. Borowski, K.H., "Religion and Politics in Post-World War II Poland", in Hadden, J.K. and Shupe, A . (Eds), Prophetic Religions and Politics, Paragon House, New York, NY, 1986.

25. Gordon, A ., Jews in Suburbia, Beacon Press, Boston, MA, 1959.

26. Loudon, D.L. and Bitta, A.J.D., Consumer Behaviour: Concepts and A pplications, M cGrawHill, New York, NY, 1979.

27. Stodtbeck, F.L., "Jewish and Italian Immigration and Subsequent Status Mobility", in McClelland, D.C. (E d.), Talent and Society, Van Nostrand, Princeton, NJ, 1958.

28. Bahr, H.M., "Religious Contrasts in Family Role Definitions and Performance: Utah M ormons, Catholics, Protestants, and Others", Journal for the Scientific Study of Religion, Vol. 21, 1982, pp. 200-17.

29. Rainwater, L., "M arital Sexuality in Four Cultures of Poverty", Journal of M arriage and the Family, Vol. 4, 1964, pp. 457-66.

30. Ingoldsby, B.B., "T he Latin-A merican Family: Familism vs. Machismo", Journal of Comparative Family Studies, Vol. 22, Spring 1991, pp. 57-62.

31. Meir, H.C., "M other-Centredness and College Youths' A ttitudes towards Social E quality for Women: Some Empirical Findings", Journal of Marriage and Family, Vol. 34, February 1972, pp. 115-21.

32. Campbell, D.F., "Religion and Values among Nova Scotia Students", Sociological A nalysis, Vol. 27, Summer 1966, pp. 80-93.

33. Delener, N. and Schiffman, L.G., "Family Decision Making: The Impact of Religious Factors", in Frazier, G., Ingene, C., A aker, D., Ghosh, A ., Kinnear, T., Levy, S., Staelin, R. and Summers, J. (E ds), Efficiency and Effectiveness in M arketing, A merican M arketing Association, 1988, pp. 80-83.

34. Engel, J.F., "Psychographic Research in a Cross-cultural Non-product Setting", A dvances in Consumer Research, Vol. 3, 1976, pp. 98-101.

35. Delener, N., "A n Examination of the Religious Influences as Predictors of Consumer Innovativeness", Journal of M idwest Marketing, Vol. 5, Spring 1990, pp. 167-78. 
36. Hirschman, E.C., "Religious Differences in Cognitions regarding Novelty Seeking and Information Transfer", in Mitchell, A .A . (Ed.), A dvances in Consumer Research, V ol. 10, A ssociation for Consumer Research, St Louis, M O, 1982, pp. 228-33.

37. Clark, J.W., "Personal Religiousness and Retail Store Evaluative Criteria”, in King, R.L. (E d.), M arketing: Perspectives for the 1990s, Southern Marketing A ssociation, New Orleans, LA, November 1993, pp. 102-05.

38. Wilkes, R.E., Burnett, J.J. and Howell, R.D., "On the M eaning of Religiosity in Consumer Research", Journal of the A cademy of M arketing Science, Vol. 14, Spring 1986, pp. 47-56.

39. Jones, M.B., "Religious V alues and A uthoritarian Tendency", Journal of Social Psychology, Vol. 48, 1958, pp. 83-9.

40. Kaiser, D.L., "Religious Problem-solving Styles and Guilt", Journal for the Scientific Study of Religion, Vol. 30, 1991, pp. 94-8.

41. Pargament, K.I., Kennell, J., Hathaw ay, W., Grevengoed, N., New man, J. and Jones, W., "Religion and the Problem-solving Process; T hree Styles of Coping", Journal for the Scientific Study of Religion, Vol. 27, 1988, pp. 90-104.

42. Pargament, K.I. and Hahn, J., "God and the Just W orld: Causal and Coping A ttributions in Health Situations", Journal for the Scientific Study of Religion, Vol. 25, 1986, pp. 193-207.

43. Spilka, B., Shaver, P. and Kirkpatrick, L., "A General A ttribution Theory for the Psychology of Religion", Journal for the Scientific Study of Religion, V ol 24, 1985, pp. 1-20.

44. Wilson, J., Religions in A merican Society, Prentice-Hall, Englewood Cliffs, N ew Jersey, NJ, 1978.

45. D’A ntonio, W.V., "Family and Religion”, Journal for the Scientific Study of Religion, V ol. 19, 1980, pp. 89-104.

46. Lampe, P.E., "A ndrogyny and Religiosity", International Journal of Women's Studies, Vol. 4, 1981, pp. 24-34.

47. Gorsuch, R.L. and Smith, C.S., "A ttributions of Responsibility to God: A n Interaction of Religious B eliefs and Outcomes", Journal for the Scientific Study of Religion, Vol. 22, 1983, pp. 340-52.

48. Spilka, B. and Schmidt, G., "General A ttribution Theory for the Psychology of Religion: The Influence of Event-Character on A ttributions to God", Journal for the Scientific Study of Religion, Vol. 22, 1983, pp. 326-40.

49. Lupfer, M.B., Hopkinson, P.L. and Kelley, P., "A n Exploration of the A ttributional Styles of Christian Fundamentalists and of A uthoritarians", Journal for the Scientific Study of Religion, Vol. 27, 1988, pp. 389-98.

50. Putney, S. and Middletown, R., "Dimensions and Correlates of Religious Ideologies", Social Forces, Vol. 39, 1961, pp. 285-90.

51. Stanley, G., "Personality and A ttitude Correlates of Religious Conversion", Journal for the Scientific Study of Religion, Vol. 4, 1974, pp. 60-63.

52. Frenkel-Brunswick, E., "Further Exploration by a Contributor to 'T he A uthoritarian Personality' ", in Christie, R. and Jahoda, M. (Eds), Studies in the Scope and M ethod of the A uthoritarian Personality", Free Press, Glencoe, IL, 1954, pp. 226-75.

53. Photiadis, J. and Biggar, J., "Dimensions and Correlates of Religious Ideologies", Social Forces, Vol. 39, 1961, pp. 285-90.

54. Shils, E.A., "A uthoritariansim: Right Left", in Christie, R. and Jahoda, M. (Eds), Studies in the Scope and M ethod of 'T he A uthoritarian Personality' ", The Free Press, Glencoe, IL, 1954, pp. 24-9.

55. A dorno, T.W., Frenkel-Brunswick, E., Levinson, D.J. and Sanford, R.N., T he Authoritarian Personality, W.W. Norton \& Co., New York, NY, London, 1982.

56. Van Jzendoorn, M.H., "M oral Judgement, A uthoritarianism and Ethnocentrism", The Journal of Social Psychology, Vol. 129, 1990, pp. 37-45. 


\section{European Journal of Marketing 28,5}

\section{2}

57. Demerath, N.J. III, Social Class in A merican Protestantism, Rand McNally, Chicago, IL, 1965.

58. Ragsdale, D.J. and Durham, K.R., "A udience Response to Religious Fear A ppeals", Review of Religious Research, Vol. 28, September 1986, pp. 40-50.

59. Greeley, A.M., "A Note on the Origins of Religious Differences", Journal for the Scientific Study of Religion, Vol. 3, 1963, pp. 21-31.

60. Vosburgh, M.G. and Juliani, R.N., "Contrasts in Ethnic Family Patterns: The Irish and the Italians", Journal of Comparative Family Studies, Vol. 21, Summer 1990, pp. 269-84.

61. Rokeach, M., T he Open and Closed M ind, Basic Books, New York, NY, 1960.

62. Warshay, L., Goldman, M. and Biddle, E., "A nomie and F Scores as Related to Social Characteristics", Journal of Social Psychology, Vol. 62, 1964, pp. 117-23.

63. Bock, D.C. and Warren, N.C., "Religious Belief as a Factor in Obedience to Destructive Commands", Review of Religious Research, Vol. 13, 1972, pp. 185-91.

64. Hart, A.D., Coping with Depression in the Ministry and Other Helping Professions, Word Books, Waco, 1984.

65. Welch, M.R., Tittle, C.R. and Petee, T., "Religion and Deviance among A dult Catholics: A Test of the 'Moral Communities' Hypothesis", Journal for the Scientific Study of Religion, Vol. 30, 1991, pp. 159-72.

66. EIms, A.C. and Milgram, S., "Personality Characteristics A ssociated with Obedience and Defiance tow ard Authoritative Commands", Journal of Experimental Research in Personality, Vol. 1, 1966, pp. 282-9.

67. Lazarus, R. and Folkman, S., Stress, A ppraisal and Coping, Springer Publishing Company, New York, NY, 1984.

68. Rokeach, M., "Value Systems in Religion”, Review of Religious Research, Vol. 11, 1969, pp. 3-23.

69. Rokeach, M., Understanding Human Values: Individual and Societal, Free Press, New Y ork, NY, 1979.

70. Donahue, M.J., "Intrinsic and Extrinsic Religiousness: Review and M eta-A nalysis", Journal of Personality and Social Psychology, Vol. 48, 1985, pp. 400-19.

71. Finke, R., "Demographics of Religious Participation: A n E cological A pproach, 1850-1980", Journal for the Scientific Study of Religion, Vol. 28, 1989, pp. 45-58.

72. Siiter, R. and Ellison, K.W., "Perceived A uthoritarianism in Self and Others by M ale College Students and Police Officers", Journal of A pplied Social Psychology, Vol. 14, 1984, pp. 33440.

73. Simas, K. and M cCarrey, M., "Impact of Recruiter A uthoritarianism and A pplicant Sex on Evaluation and Selection Decisions in a Recruitment Interview A nalogue Study", Journal of A pplied Psychology, Vol. 64, 1979, pp. 483-91.

74. Johnson, R.C., Johnson, C. and Martin, L., "A uthoritarianism, Occupation, and Sex Role Differentiation of Children", Child Development, V ol. 32, 1961, pp. 271-6.

75. Blood, R.O. and Wolfe, D.M., Husbands and W ives: The Dynamics of Married Living, The Free Press, Glencoe, IL, 1960.

76. Davis, H.L., "Decision Making within the Household”, Journal of Consumer Research, Vol. 2, March 1976, pp. 241-60.

77. Cronbach, L.J., "Coefficient A Ipha and the Internal Structure of Tests", Psychometrika, Vol. 16 N o. 3, September 1951, pp. 297-334.

78. A nastasi, A ., Psychological Testing, M acmillan Publishing, New York, NY, 1976, pp. 116-18.

79. Nunnally, J.C. Jr, Psychometric T heory, M cGraw-Hill, New York, NY, 1967, p. 226.

80. Peter, J.P. and Ryan, M.J., "A n Investigation of Perceived Risk at the Brand Level", Journal of M arketing Research, Vol. 13, May 1976, pp. 184-8. 
81. Engel, J.F., Blackwell, R.D. and Miniard, P.W., Consumer Behaviour, 6th edition, Dryden Press, Hinsdale, IL, 1990.

\section{Further Reading}

Allport, G.W. and Ross, J.M., "Personal Religious Orientation and Prejudice", Journal of Personality and Social Psychology, Vol. 5, 1967, pp. 432-43.

Baker, M. and Gorsuch, R., "Trait A nxiety and Intrinsic-Extrinsic Religiousness", Journal for the Scientific Study of Religion, Vol. 21, 1982, pp. 119-22.

Batson, C.D. and Flory, J.D., "Goal-relevant Cognitions A ssociated with Helping by Individuals High on Intrinsic, End Religion", Journal for the Scientific Study of Religion, Vol. 29, 1990, pp. $346-60$.

Batson, C.D. and Ventis, W.L., T he Religious Experience, Oxford University Press, New York, NY, 1982.

Masters, K.S., "Of Boons, Banes, Babies, and Bathwater: A Reply to the Kirkpatrick and Hood Discussion of Intrinsic-Extrinsic Religious Orientation", Journal for the Scientific Study of Religion, Vol. 30, 1991, pp. 312-17.

Morris, R.J., Hood, R.W. Jr and Watson, P.J., "A Second Look at Religious Orientation, Social Desirability, and Prejudice", Bulletin of the Psychonomic Society, Vol. 27, 1989, pp. 81-4. 